chiều cao phụ thuộc nhiều yếu tố như: mức độ nặng (nồng độ GH đỉnh thời điểm chẩn đoán), tuổi bắt đầu điều trị, liều điều trị hay chiều cao di truyền của bố mẹ.

Trong báo cáo của chúng tôi, tại thời điểm chẩn đoán, chiều cao của 3 bệnh nhân đều $(<-4$ SD) theo TCYTTG, sau 3 năm điêuu trị, chiều cao 3 bệnh nhân đã bắt kịp được tốc độ tăng trưởng bình thường. Kết quả này phù hợp các nghiên cứu trên thế giới, với giả thuyết tốc độ tăng trưởng chiêu cao trong những năm sau thấp hơn so với năm đầu do sư xuất hiên của kháng thể chống lại GH tái tổ hợp. Vì vâyy, chúng tôi tin rằng báo cáo này có ý nghĩa trong việc bổ sung vào y văn là việc sử dụng hormon tăng trưởng tái tổ hợp là an toàn và hiệu quả.

\section{KẾT LUÂN}

Cả 3 bệnh nhân bị thiếu hụt hormon tăng trưởng được chẩn đoán sớm, chiêu cao tại thời điểm chẩn đoán chậm nặng và được điều trị thay thế bằng $\mathrm{GH}$ tái tổ hợp tiêm dưới da hằng ngày. Báo cáo này chỉ ra hiệu quả và an toàn của thuốc, tốc độ tăng trưởng chiêu cao lớn nhất trong năm đầu $14-18 \mathrm{~cm} /$ năm và giảm dần trong các năm sau; không có tác dụng không mong muốn nào được ghi nhận trên bệnh nhân. Tuy nhiên, cần có các nghiên cứu lớn hơn tại Việt Nam để khẳng định tính hiệu quả và an toàn của thuốc.

\section{TÀI LIẸU THAM KHẢO}

1. Dattani M., and Preece M. (2004). Growth hormone deficiency and related disorders: insights into causation, diagnosis, and treatment. Lancet Lond Engl, 363(9425), 1977-1987.

2. Takeda A., Cooper K., Bird A, et al. (2010). Recombinant human growth hormone for the treatment of growth disorders in children: a systematic review and economic evaluation. Health Technol Assess Winch Engl, 14(42), 1-209.

3. Gharib H., Cook D.M., Saenger P.H, et al. (2003). American Association of Clinical Endocrinologists medical guidelines for clinical practice for growth hormone use in adults and children--2003 update. Endocr Pract Off J Am Coll Endocrinol Am Assoc Clin Endocrinol, 9(1), 64-76.

4. Grimberg A., DiVall S.A., Polychronakos $C_{\text {, }}$ et al . (2016). Guidelines for Growth Hormone and Insulin-Like Growth Factor-I Treatment in Children and Adolescents: Growth Hormone Deficiency, Idiopathic Short Stature, and Primary Insulin-Like Growth Factor-I Deficiency. Horm Res Paediatr, 86(6), 361-397.

5. Ayyar V.S. (2011). History of growth hormone therapy. Indian J Endocrinol Metab, 15(3), 162165.

6. Hou L., Luo X., Du M, et al. (2009). [Efficacy and safety of recombinant human growth hormone solution in children with growth hormone deficiency in China: a multicenter trial]. Zhonghua Er Ke Za Zhi Chin J Pediatr, 47(1), 48-52.

7. Korpal-Szczyrska M., Dorant B., Kamińska H, et al. (2006). Evaluation of final height in patients with pituitary growth hormone deficiency who were treated with growth hormone replacement. Endokrynol Diabetol Chor Przemiany Materii Wieku Rozw Organ Pol Tow Endokrynol Dzieciecych, 12(1), 31-34.

8. Salah N., Abd El Dayem S.M., El Mogy F, et al. (2013). Egyptian growth hormone deficient patients: demographic, auxological characterization and response to growth hormone therapy. J Pediatr Endocrinol Metab JPEM, 26(34), 257-269.

\title{
ĐÁNH GIÁ NGUY CƠ TỬ VONG Ở BỆNH NHÂN NHIỄM KHUẨN NĂNG Có TỔN THƯƠ'NG THẬN CẤP
}

\section{TÓM TĂT}

Mục tiêu: Đánh giá một số yếu tố nguy cơ tới tổn thương thận và tử vong ở bệnh nhân nhiễm khuẩn năng. Đối tướng và phương pháp nghiên cứu: Bệnh nhân nhiểm khuẩn nặng điêu trị tại khoa Hồi sức tích cức bênh viện Bach Mai theo phướng pháp mô tả tiến cứu. Kết quả: Nhiễm khuẩn nặng làm tăng nquy cơ tổn thương thận 2,1 lần, $p<0,05$; Bệnh nhân nhiềm

*Trung tâm Chống độc -Bênh viên Bach Mai.

Chịu trách nhiệm chính: Đặng Thị Xuân

Email: xuandangthi17@gmail.com

Ngày nhận bài: 18.12 .2020

Ngày phản biên khoa hoc: 22.01.2021

Ngày duyệt bài: 5.2 .2021
Đặng Thị Xuân*

khuẩn nặng có tổn thương thân cấp tử vong rất cao $61,6 \%$, nguy cơ tử vong gấp 4,7 lần so với bệnh nhân không tổn thương thận (OR 4,7; $p<0,001)$. Những bệnh nhân nặng phải lọc máu tỉ lệ tử vong lên tới $75 \%$, nguy cớ tữ vong gấp 21 lần so với những bệnh nhân không phải loc máu (OR 21; $\mathrm{p}<0,001)$. Nhóm bệnh nhân suy thận muộn sau khi vào viện tử vong cao nhất $(80 \%, p<0,01)$, thường trong tình trang suy đa tạng; nguy cơ tử vong gấp 8 lần nhóm mức độ nhẹ khi vào viện, (OR 8,$0 ; p<0,001)$. Kết luân: Nhiễm khuẩn nặng làm tăng nguy cơ tổn thương thận cấp. Nhiễm khuẩn năng có tổn thương thân tăng nguy cơ tử vong, đặc biệt nhóm nă̆ng phải lọc máu vàtổn thương thân muộn sau vào hồi sức.

Tư khóa: Tổn thương thận cấp, nhiễm khuẩn nặng, RIFLE. 


\section{SUMMARY \\ EVALUATION OF FACTORS RELATED TO MORTALITY IN SEVERE SEPSIS PATIENTS}

Objective: Evaluation of factors related to acute renal failure and death in patients with severe sepsis. Subjects and Methods: A prospective observational study was conducted in patients with severe seppsis treated at ICU, Bach Mai hospital. Results: Severe sepsis increased the risk of AKI 2.1 times, $p<0.05$. The combination of AKI and severe sepsis is associated with a $61.6 \%$ mortality, increased the risk of death 4.7 timesas compared with AKI alone, $p$ $<0.001$. Patients on dialysis have a mortality rate of up to $75 \%$, and the risk of death is 21 times that of non-dialysis patients (OR 21; $\mathrm{p}<0.001)$. The group of patients with AKI after admission the highest death $(80 \%)$, p < $<.01$; The risk of death was 8,0 times higher than of the group with mild upon admission, $\mathrm{p}$ $<0.001$. Conclusion: Severe infections increase the risk of AKI, severe infections with AKI increase the risk of death, especially in the severe group that requires hemodialysis and AKI after ICU admitted.

Keywords: acute renal failure, severe sepsis, RIFLE

\section{I. ĐẶT VẤN ĐỀ}

Nhiễm khuẩn là bệnh cảnh lâm sàng thường gặp tại các khoa hồi sức cấp cứu. Nhiểm khuẩn nặng, đặc biệt là sốc nhiễm khuẩn là yếu tố nguy cơ quan trọng gây tổn thương thận cấp. Các nghiên cứu cho thấy tỉ lệ tổn thương thận cấp chiếm $20-80 \%$ trong nhiễm khuẩn nặng và sốc nhiễm khuẩn. Tử vong của các bệnh nhânnhiễm khuẩn nặng có tổn thương thận cững cao hơn rất nhiều so với tổn thương thận đơn thuần. Cơ chế chủ yếu của tổn thương thận cấp trong nhiễm khuẩn là nội độc tố, các chất trung gian hệ thống và tại thận của phản ứng viêm, các chẩt nội môi của hệ thần kinh- vỏ thận trong cơ thể [1], [7].

Ở Việt Nam, còn ít nghiên cứu về tổn thương thận cấp ở bệnh nhân nhiễm khuẩn nặng. Có tác giả nhận thấy $71,9 \%$ bệnh nhân hồi sức có liên quan tới tình trạng nhiểm khuẩn. Với mong muốn tìm hiểu về các nguy cơ gây tử vong do tổn thương thận ở bệnh nhân nhiềm khuẩn, hạn chế mức độ tổn thương thân và tử vong do tổn thương thận cấp, đặc biệt là ở bệnh nhân nhiễm khuẩn nặng và sốc nhiểm khuẩn chúng tôi tiến hành nghiên cứu nhằm: Đánh giá một số yếu tố liên quan tới tổn thương thận và tử vong ở bệnh nhân nhiễm khuẩn nặng.

\section{II. ĐốI TƯợNG VÀ PHƯƠNG PHÁP NGHIÊN CỨU \\ 2.1. Đối tượng nghiên cứu}

- Tiêu chuẩn chọn bệnh nhân: Bệnh nhân nhiễm khuẩn nặngtừ 18 tuổi trở lênđiều trị tại khoa hồi sức tích cực bệnh viện Bạch Mai trong thời gian từ 2011 đển 2012.
*Chẩn đoán nhiễm khuẩn nặng: theo tiêu chuẩn của Hội lồng ngực Hoa Kỳ/Hội Hồi sức tích cực Hoa Kỳ [3]:

- Có hội chứng đáp ứng viêm hệ thống (SIRS)

gồm ít nhất 2 trong 4 triệu chứng sau:

+ Thân nhiệt trung tâm $>38^{\circ} \mathrm{C}$ hoặc $<36^{\circ} \mathrm{C}$.

+ Nhịp thở >20 lân/phút hoặc $\mathrm{PaCO}_{2}<32 \mathrm{mmHg}$.

+ Nhịp tim > 90 lần/phút.

+ Bạch cầu $>12.000 / \mathrm{mm}^{3}$ hoặc $<4000 / \mathrm{mm}^{3}$.

- Hội chứng nhiễm khuẩn toà̀n thân (sepsis) là SIRS do vi trùng gây nên (có ổ nhiễm trùng hoặc cấy máu dương tính).

Chẩn đoán sepsis theo tiêu chuẩn mới (sepsis 3) bao gồm nhiếm trùng (infection) + qSOFA $\geq$ 2 điểm (ngoài khoa Hồi sức) hoặc SOFA $\geq$ điểm (trong khoa Hồi sức).

- Nhiễm khuẩn nặng: là sepsis phối hợp với tụt huyết áp (còn đáp ứng với bù dịch) và/hoăc phối hợp với giảm tưới máu hoặc rối loạn chức năng của một hay nhiều cơ quan: suy hô hấp cấp tiến triển; rối loạn ý thức; thiểu niệu; rối loạn đông máu; toan chuyển hoá không giải thích được; tăng acid lactic máu.

- Sốc nhiễm khuẩn là nhiễm khuẩn nặng có huyết áp tâm thu $<90 \mathrm{mmHg}$ hoặc giảm > $40 \mathrm{mmHg}$ so với huyết áp cơ bản của bệnh nhân, không đáp ứng với bù dịch hoặc phải dùng thuốc vận mạch để duy trì huyết áp, có biểu hiện giảm tưới máu tổ chức hoặc rối loạn chức năng ít nhất một cơ quan (rối loạn ý thức, thiểu niệu, toan chuyển hoá, tăng acid lactic).

\section{- Tiêu chuẩn loại trừ:}

+Bệnh nhân tổn thương thận mạn: tiền sử bệnh thận tiết niệu đã có tăng ure/creatinin từ trước, siêu âm thẩy hai thận nhỏ, có triệu chứng thiếu máu, tăng huyết áp của tổn thương thận mạn.

+ Tổn thương thận cấp do nguyên nhân khác không liên quan tới nhiễm khuẩn.

\subsection{Phương pháp nghiên cứu}

2.2.1. Thiết kế nghiên cứu: Nghiên cứu mô tả

2.2.2. Tiến hành nghiên cứu: đánh giá tình trạng và tiến triển theo các chỉ số:

\section{- Lâm sàng}

+ Thông tin bệnh nhân: tuổi, giới tính, nghề nghiệp, tiền sử bệnh tật

+ Toàn thân: mạch, huyết áp trung bình, tình trạng tụt huyết áp, thiếu dịch, tần số thở, SpO2, suy hô hấp, nước tiểu

\section{Cận lâm sàng}

+Cổng thức máu, sinh hóa máu: ure, creatinin, điện giải đồ, procalcitonin

+Khí máu động mạch, tổng phân tích nước tiểu, điện giải niệu 
+ Các xét nghiệm tìm nguyên nhân và biến chứng: siêu âm, xquang, cấy máu, cấy dịch ổ nhiễm khuẩn.

- Tính điểm APACHE II và SOFA, đánh giá biến chứng, mức độ tổn thương thận, phải can thiệp lọc máu. So sánh giữa bệnh nhân có và không có tổn thương thận để đánh giá các nguy cơ.

Chẩn đoán tổn thương thận cấp: creatinin máu $\geq 130 \mu \mathrm{mol} / \mathrm{l}$, áp dụng phân độ tổn thương thận theo RIFLE [2]:

+ Mức độ $\mathrm{R}$ (Risk): creatinin huyết thanh $130-170 \mu \mathrm{mol} / \mathrm{l}$

+ Mức độ I (Injury): creatinin huyết thanh $171-259 \mu \mathrm{mol} / \mathrm{l}$

+ Mức độ $F$ (Failure): creatinin huyết thanh $\geq 260 \mu \mathrm{mol} / \mathrm{l}$

2.3. Xử lý số liệu. Số liệu được xử lý theo phương pháp thống kê y học, sử dụng phần mềm SPSS 16.0. So sánh giá trị 2 trung bình bằng Student test (Mann-Witney U test nếu phân bố không chuẩn), so sánh nhiều giá trị trung bình bằng bằng ANOVA test, so sánh tỷ lệ \% bằng test $X 2$ hoặc Fisher Exact test, đánh giá sự liên quan bằng tỉ suất chênh $\mathrm{OR}$ và phân tích đa biến, mức ý nghĩa thống kê 95\%.

\section{KẾT QUẢ NGHIÊN CỨU}

Trong thời gian nghiên cứu, chúng tôi có 246 bệnh nhân (BN) nhiễm khuẩn nặng, trong đó 134 BN không tổn thương thận (54,5\%), 112 bệnh nhân $(45,5 \%)$ có tổn thương thận cấp (AKI)

3.1. Đặc điểm chung của các bệnh nhânnghiền cứu

- Phân bố về giới:

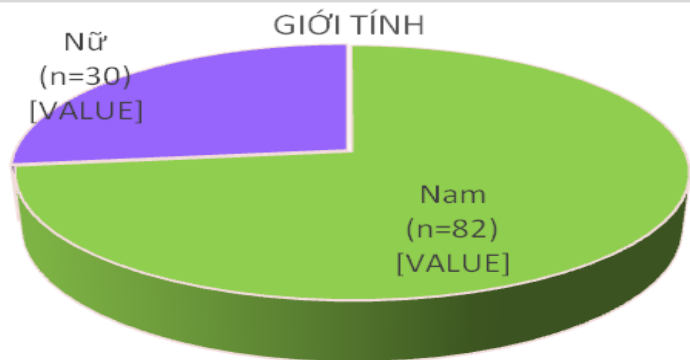

Biểu đồ 1: Phân bố về giới

Nhân xét: Ỡ các bênh nhân tổn thương thận cấp, bểnh nhân nam là $82 / 112 \mathrm{BN}(73,2 \%)$, nữ là 30/112 BN (26,8\%), tỉ lệ Nam/Nữ là 2,7:1

- Phân bố bệnh nhân theo tuổi

+ Tuổi trung bình của bệnh nhân có tổn thương thận là $61,3 \pm 16,22$ cao hơn nhóm không tổn thương thận là $59,7 \pm 18,45(p<0,05)$.

+ Tỉ lệ tổn thương thận cấp 86,6\% ở bệnh nhân $\geq 45$ tuổi, ở người cao tuổi $\geq 65$ tuổi là 42,7\%.

\subsection{Một số yếu tố liên quan tổn thương thận và tử vong ở bệnh nhân nhiễm khuẩn nặng}

Bảng 3.1. Các yếu tố nguy cơ làm tổn thương thận cấp

\begin{tabular}{|c|c|cc|c|}
\hline Thống số & Hệ số beta & \multicolumn{2}{|c|}{ OR (95\% CI) } & P \\
\hline Suy đa tạng ( $\geq 2$ tạng) & 1,99 & 7,3 & $(2,96-18,10)$ & $<0,001$ \\
\hline Tăng áp lực ố bụng & 1,82 & 6,2 & $(2,24-16,99)$ & $<0,001$ \\
\hline Tiêu cơ vân & 1,62 & 5,1 & $(2,56-10,02)$ & $<0,001$ \\
\hline Thở máy & 1,34 & 3,8 & $(2,07-7,10)$ & $<0,01$ \\
\hline Thiếu dịch & 1,25 & 3,5 & $(1,73-7,02)$ & $<0,001$ \\
\hline Suy tim & 0,94 & 2,6 & $(1,43-4,55)$ & $<0,01$ \\
\hline Sốc & 0,93 & 2,5 & $(1,23-5,23)$ & $<0,05$ \\
\hline Suy gan, rối loạn đông máu & 0,91 & 2,5 & $(1,09-5,64)$ & $<0,05$ \\
\hline Điểm APACHE II vào viện $\geq 20$ & 0,83 & 2,3 & $(1,31-4,03)$ & $<0,01$ \\
\hline Nhiếm khuẩn nặng & 0,74 & $\mathbf{2 , 1}(1,11-3,95)$ & $<0,05$ \\
\hline Tuổi cao $\geq 65$ & 0,58 & $1,8(1,02-3,13)$ & $<0,05$ \\
\hline Đái tháo đường & $-0,36$ & $0,70 \quad(0,41-1,20)$ & $>0,05$ \\
\hline
\end{tabular}

Nhận xét: Khi phân tích hồi qui đa biến, chúng tôi thây nhiều nguyên nhân làm tăng nguy cơ tổn thương thận ở bệnh nhân hồi sức, đặc biệt là tình trạng suy đa tạng và tình trạng nặng của BN.

- Nhiễm khuẩn nặng làm tăng nguy cở tổn thương thận cấp lển 2,1 lần, $p<0,05$.

Bảng 3.2. Liên quan giữa tổn thương thận cấp với tử vong ở bệnh nhân nhiễm khuẩn nặng

\begin{tabular}{|c|c|c|c|c|}
\hline Kết quá Nhóm & $\begin{array}{c}\text { AKI } \\
(112 \mathrm{BN})(1)\end{array}$ & $\begin{array}{l}\text { Không AKI } \\
\text { (134 BN) (0) }\end{array}$ & $\begin{array}{c}\text { Tổng số bệ̂nh nhân } \\
\text { nhiê̂́m khuẩn }\end{array}$ & $\begin{array}{l}\text { p giữa } \\
(0) \text { và (1) }\end{array}$ \\
\hline Khỏi & $43(38,4 \%)$ & $100(74,6 \%)$ & 143 & \multirow{3}{*}{$\begin{array}{l}\mathbf{p}<0,001(\text { OR 4,7 } \\
\text { (CI95\%: } 2,7-8,1)\end{array}$} \\
\hline Tử vong & $69(61,6 \%)$ & $34(25,4 \%)$ & 103 & \\
\hline Công & $112(100 \%)$ & $134(100 \%)$ & 246 & \\
\hline
\end{tabular}

Nhận xét: Bệnh nhân nhóm nhiềm khuẩn có tổn thương thận cấp tỉ lệ tử vong rất cao (67\%), nguy cơ tử vong cao gấp 4,7 lần so với nhóm không có tổn thương thận $(p<0,001)$. 
Bảng 3.3. Liên quan giữa mức độ nặng phải lọc máu với tử vong

\begin{tabular}{|c|c|c|c|c|}
\hline $\begin{array}{l}\text { Nhóm } \\
\text { Kết quâ }\end{array}$ & $\begin{array}{l}\text { Phải lọc máu } \\
\text { (1) }\end{array}$ & $\begin{array}{c}\text { Không phải lọc } \\
\text { máu (0) }\end{array}$ & $\begin{array}{c}\text { Tống số bệnh } \\
\text { nhân AKI }\end{array}$ & $\begin{array}{l}\text { p giữa } \\
(0) \text { và (1) }\end{array}$ \\
\hline Khỏi & $22(25,0 \%)$ & $31(61,8 \%)$ & 43 & \multirow{3}{*}{$\begin{array}{l}\text { p< } \mathbf{0 , 0 0 1} \text { (OR 21; } \\
\text { (CI95\%: } 5,7-77,2)\end{array}$} \\
\hline Tử vong & $66(75,0 \%)$ & $3(8,8 \%)$ & 69 & \\
\hline Công & $88(100 \%)$ & $34(100 \%)$ & 112 & \\
\hline
\end{tabular}

Nhận xét: Số bệnh nhân có tốn thương thânnở bệnh nhân nhiếm khuấn nặng cần lọc máu là $88 / 112 \mathrm{BN}(78,6 \%)$, những bệnh nhân này có tỉ lệ tử vong rất cao 66/88 BN (75\%), nguy cơ tử vong cao gấp 21 lần so với những bệnh nhân không phải lọc máu.

Bảng 3.4. Mức độ tổn thương thận lúc vào viện và tử vong

\begin{tabular}{|c|c|c|c|c|c|}
\hline \multirow{2}{*}{$\begin{array}{l}\text { Mức độ tổn thương thận lúc } \\
\text { vào viện }\end{array}$} & \multicolumn{5}{|c|}{ Mức độ tốn thương thận lúc ra viện } \\
\hline & Hết AKI & $\mathbf{R}$ & $\mathbf{I}$ & $\mathbf{F}$ & Tử vong \\
\hline $\operatorname{Nvv}(n=30)$ & $7 *$ & 10 & 9 & 4 & $24(80,0 \%)^{*}$ \\
\hline $\operatorname{Rvv}(n=30)$ & $18(60.0 \%)^{*}$ & 4 & 6 & 2 & $10(33,3 \%)^{*}$ \\
\hline $\operatorname{Ivv}(n=24)$ & 9 & 2 & 6 & 7 & $17(70.8 \%)$ \\
\hline Fvv $(n=28)$ & 7 & 0 & 3 & 18 & $18(64.3 \%)$ \\
\hline Cộng ( $n=112$ BN) & $41(36.6 \%)$ & 16 & 24 & 31 & $69(61,6 \%)$ \\
\hline $\begin{array}{l}\text { So sánh tử vong } \\
\text { Nvv - Rvv }\end{array}$ & \multicolumn{4}{|c|}{$p<0,01$} & $\begin{array}{l}\text { Nvv-Rvv OR: 8,0 } \\
(p<0,001)\end{array}$ \\
\hline
\end{tabular}

Nhận xét: BN tốn thương thận sau khi vào viện có tỉ lệ tử vong cao nhất $24 / 30$ BN (80\%), $p<0,01$ và nguy cơ tử vong gấp 8 lần so với nhóm tổn thương mức độ nhẹ $R$ khi vào viện, $p<0,001$; hồi phục chức năng thận thấp nhất $7 / 30(23,3 \%)$

- Những bệnh nhân tổn thương thận mức độ nhẹ ngay khi vào viện có tỉ lệ hồi phục chức năng thận cao nhất $18 / 30(60,0 \%)$ và tử vong thấp nhất $10 / 30 \mathrm{BN}(33,3 \%), \mathrm{p}<0,01$.

Bảng 3.5. Một số đặc điểm bệnh nhân sống và tử vong ở bệnh nhân AKI

\begin{tabular}{|c|c|c|c|}
\hline Thông số & Tử vong $(n=69)$ & Sống $(n=43)$ & $\mathbf{p}$ \\
\hline Tuối (năm) & $63,3 \pm 15,30$ & $58,0 \pm 17,29$ & $>0,05$ \\
\hline Điểm APACHEII vào viện & $24,3 \pm 8,12$ & $22,1 \pm 5,80$ & $>0,05$ \\
\hline Điểm APACHEII lúc AKI nặng nhất & $32,6 \pm 8,96$ & $22,8 \pm 5,81$ & $<0,001$ \\
\hline Điếm SOFA vào viện & $7,4 \pm 4,06$ & $5,8 \pm 3,08$ & $<0,05$ \\
\hline Điểm SOFA lúc AKI nặng nhất & $10,7 \pm 3,84$ & $6,3 \pm 3,0$ & $<0,001$ \\
\hline Số tạng suy & $4,0 \pm 0,75$ & $3,0 \pm 0,80$ & $<0,001$ \\
\hline Thời gian nằm hôi sức (ngày) & 8,8 & 13,3 & $<0,05^{*}$ \\
\hline Thời gian nằm viện (ngày) & 12,2 & 15,9 & $>0,05^{*}$ \\
\hline $\begin{array}{c}\text { Số tạng suy } \geq 3(n=106) \\
<3(n=6)\end{array}$ & $\begin{array}{c}69(65,1 \%) \\
0(0 \%)\end{array}$ & $\begin{array}{c}37(34,9 \%) \\
6(14 \%)\end{array}$ & $\begin{array}{l}\text { p<0,01 (OR:2,9; } \\
95 \% \text { CI: } 2,2-3,7)\end{array}$ \\
\hline
\end{tabular}

(* Mann-Witney U test)

Nhận xét: so sánh nhóm sống và tử vong ở bệnh nhân AKI, chúng tôi thây:

- Tuổi của nhóm sống và tử vong không khác nhau, $\mathrm{p}>0,05$.

- Điểm APACHE II và SOFA nhóm tử vong cao hơn nhóm sống, $p<0,001$, số tạng suy cũng cao hơn, $p<0,001$. Những bệnh nhân suy $\geq 3$ tạng nguy cơ tử vong gấp 2,9 lần bệnh nhân suy $<3$ tang, $\mathrm{p}<0,01$.

- Thời gian nằm hồi sức của $\mathrm{BN}$ tử vong ngắn hơn nhóm sống, $p<0,05$

\section{BÀN LUÂ̂N}

4.1. Đặc điểm chung của bệnh nhân AKI ở nhóm nhiếm khuẩn

- Phân bố về giới: Theo biểu đồ 3.1. tỉ lệ bệnh nhân nam là $73,2 \%$ cao hơn nhiều so với nữ là $26,8 \%$, tỉ lệ nam/nữ là $2,7 / 1$. Nghiên cứu của Bagshaw S.M. nam giới là $59,5 \%$, cũng cao hơn nữ giới [1]. Một số nguyên nhân thường gây tổn thương thận như: viêm tụy cấp, xơ gan, bệnh tim mạch... hay gặp ở nam giới.

Phân bố bệnh nhân theo tuổi: tuổi trung bình của các bệnh nhân là 61,3 tuổi, cao hơn nhóm không tổn thương thận là 58,4 tuổi; $p<0,05$, nghiên cứu của Piccinni P. là 66 tuổi [6]. Tác giả Bellomo R. khi phân tích về tuổi bệnh nhân AKI từ các nghiên cứu trong vòng 30 năm thì thấy tuổi trung bình có xu hướng tăng lên [2]. Các bệnh nhân tuổi cao thường có bệnh mạn tính, nguy cơ tổn thương thận cao hơn. 


\subsection{Một số yếu tố nguy cơ tổn thương thận và tử vong ở bệnh nhân nhiễm khuẩn \\ *Các yếu tố nguy cơ làm tổn thương}

thân cấp. Khi phân tích hồi qui đa biến các yếu tố liên quan tới tổn thương thân cấp chúng tôi nhận thấy nhiễm khuẩn nặng làm tăng nguy cơ tổn thương thận cấp lên 2,1 lần, $p<0,05$.

Phân tích của Bellomo $R$. và công sự trong nhiều năm cũng đưa ra sốc nhiểm khuẩn là nguyên nhân chính của AKI, sau đó là phẫu thuật nặng, sốc tim [2].

Một nghiên cứu đa trung tâm, Uchino $S$. và nhóm tác giả đã nhận thấy 47,5\% bệnh nhântổn thương thận cấp liên quan với tình trạng sốc nhiễm khuẩn, 34\% liên quan với phẫu thuật lớn, $27 \%$ liên quan với sốc tim, $26 \%$ liên quan với thiếu thể tích và $19 \%$ liên quan với sử dung thuốc [8]. Rất nhiều các nghiên cứu đã chỉ ra nhận xét nhiễm khuẩn nặng là yếu tố thường gặp nhất liên quan tới tổn thương thận cấp [1], [3].

*Liên quan giữa tổn thương thận cấp với tử vong ở bệnh nhiếm khuẩn. Khi so sánh tử vong giữa 2 nhóm có AKI và không AKI ở bệnh nhân nhiễm khuẩn nặng (bảng 3.2), chúng tôi thây bệnh nhân có tổn thương thận cấp tỉ lệ tử vong cao hơn không tổn thương thận rất nhiểu $(61,6 \%$ và $33 \%)$, cụ thể là nguy cơ tử vong gấp 4,7 lần $(p<0,001)$.

Phân tích của Schrier Robert W, tổn thương thận cấp ở bệnh nhân nhiễm khuẩn tử vong lên tới $70 \%$ so với tổn thương thận cấp đơn thuân là 45\%[8]. Nghiên cứu của De Mendonca A, Vincent và cộng sự tại 40 khoa hồi sức ở 16 nước với 1441 bệnh nhân, các tác giả thấy bệnh nhân có tổn thươning thận cấp tử vong gấp 3 lần so với không tổn thương thận $(42,8 \%$ so với $14,5 \%, p<0,01$ ) [4].

Đặc biệt, khi phân tích những bệnh nhân nặng cần phải lọc máu (lọc máu liên tục - CVVH và̀ ngắt quãng $-H D$ ), chúng tôi thấy những bệnh nhân cần phải loc máu tỉ lề tử vong tới $75 \%$. Loc máu liên tục là liệu pháp được sử dụng khá rộng rãi ở những bệnh nhân nhiểm khuẩn nặng, hổ trợ lọc các yếu tố tiền viêm, cytokin, hỗ trợ thận và các tang. Lọc máu liên tục thường được chỉ định ở những bệnh nhân nặng, tụt huyết áp, suy tim...vì vậy tỉ lệ tử vong cũng thường cao hơn. Trong nghiên cứu của mình, tác giả Metnitz P.G. còn đưa con số tử vong ở nhóm bệnh nhân nặng phải lọc máu, tử vong lên tới $90 \%$ [5]. Một ngiên cứu đa trung tâm, 23 quốc gia trên 29269 bệnh nhân hồi sức, các tác giả cũng nhận thấy những bênh nhân có AKI cần phải lọc máu chiếm $5-6 \%$ và̀ tỉ lệ tử vong cũng cao hớn hẳn những bệnh nhân không phải lọc máu [8].

Tác giả Piccinni nhận thấy $59,4 \%$ các bệnh nhân hồi phục chức nằng thận trong quá trình nằm viên, những bênh nhân nhiễm khuẩn nặng cần phải lọc máu hố trợit khả năng hồi phục hơn và, thời gian phải nằm ở khoa hồi sức dài hơn và tử vong cao hơn [6].

Dù đã có phân độ tổn thương thận hợp lý hơn, có thể phát hiện tổn thương thận từ những giai đoạn sớm để can thiệp, nhiều tiến bộ trong hồi sức bênh nhân nặng nhưng tổn thương thận cấp vẫn là một nguyên nhân quan trọng gây tử vong ở bệnh nhân hồi sức.

*Mức độ tổn thương thânn lúc vào viện và tử vong. Bệnh nhân tổn thương thận sau khi vào viện có tỉ lệ tử vong cao nhất $24 / 30 \mathrm{BN}$ $(80 \%), p<0,01$; nguy cơ tử vong gấp 8 lần so với nhóm tổn thương mức độ nhẹ $R$ khi vào viện, $p<0,001$ vàhồi phục chức năng thận thấp nhất 7/30 (23,3\%). Ngược lại, bệnh nhân tổn thương thận mức độ nhẹ khi vào viện hồi phục chức năng thân cao nhất $18 / 30(60,0 \%)$ và tử vong thấp nhất $10 / 30 \mathrm{BN}(33,3 \%), \mathrm{p}<0,01$. Đây chính là điều khác biệt của bệnh nhân hồi sức so với bệnh nhân ở khoa khác. Nhiều tác giả cũng nhận xét tương tự, những suy thận sau khi vào viện là suy thận trong tình trạng suy đa tạng, dù đã điều trị tích cực nhưng diễn biến xấu của bệnh làm ảnh hưởng chung tới tử vong của bệnh nhân chứ không đơn thuần là do tổn thương thận [6],[7], [8].

* Một số đặc điểm bệnh nhân sống và tử vong ở bệnh nhân nhiếm khuẩn nặng có AKI. Điểm $A P A C H E$ II và SOFA nhóm tử vong cao hơn nhóm sống, $p<0,001$, số tạng suy cũng cao hơn, $p<0,001$. Những bệnh nhân suy $\geq 3$ tạng nguy cơ tử vong gấp 2,9 lần bệnh nhân suy ít hơn 3 tạng, $p<0,01$. Kết quả nghiên cứu này càng cho thấy tổn thương thận dù làm tăng tử vong ở bệnh nhân nhiễm khuẩn nặng, nhưng tình nặng của bệnh nhân cũng liên quan rất nhiều tới tiên lượng và tử vong của bệnh nhân nhiễm khuẩn và hồi sức. Thời gian nằm hồi sức của bệnh nhân tử vong ngắn hơn nhóm sống $(p<0,05)$ vì nhiều bệnh nhân quá nặng, tử vong sớm, không có cơ hội để kéo dài thời gian hồi sức và điều trị.

\section{KẾT LUÂN}

- Tổn thương thận cấp gặp ở 45,5\% số bệnh nhân nhiễm khuẩn nặng. Tỉ lệ giới Nam/Nữ là $2,7: 1$.

- Tuổi trung bình là 61,3 tuổi, gặp nhiêu nhất ở người cao tuổi $\geq 65$ (42,9\%).

*Một số yếu tố nguy cơ tổn thương thận và tử vong ở bệnh nhân nhiếm khuẩn nặng: 
- Nhiễm khuẩn nặng làm tăng nguy cơ tổn thương thận 2,1 lần (OR 2,1; $p<0,05)$.

- Bệnh nhân nhiễm khuẩn nặng có tổn thương thận cấp tử vong rất cao $61,6 \%$, nguy cơ tử vong gấp 4,7 lần so với nhóm không có tổn thương thận (OR 4,7; $(p<0,001)$.

- Những bệnh nhân phải lọc máu tỉ lệ tử vong lên tới $75 \%$, nguy cơ tử vong gấp 21 lần so với những bệnh nhân không phải lọc máu (OR 21; $\mathrm{p}<0,001$ ).

- Bênh nhân xuất hiện tổn thương thận muộn sau khi vào viện tử vong cao nhất $(80 \%)$, $p<0,01$ : thường trong tình trạng bệnh nặng, suy đa tạng, nguy cơ tử vong gấp 8 lần so với nhóm tổn thương mức độ nhẹ khi vào viện (OR 8,0; $\mathrm{p}<0,001)$.

\section{TÀI LIẸU THAM KHẢO}

1. Bagshaw, S. M., et al. (2007). "Septic acute kidney injury in critically ill patients: clinical characteristics and outcomes". Clin J Am Soc Nephrol 2(3): 431-439.

2. Bellomo R., Ronco C., Kellum J A. (2004). "Acute renal failure - definition, outcome measures, animal models, fluid therapy and information technology needs: the Second International Consensus Conference of the Acute Dialysis Quality Initiative (ADQI) Group". Critical Care, 8(20, 204-212.

3. Dellinger, R. P., et al. (2013). "Surviving Sepsis Campaign: international guidelines for management of severe sepsis and septic shock, 2012". Intensive Care Med 39(2): 165-228.

4. De Mendonca A., Vincent J.L. et al. (2000). "Acute renal failure in the ICU: risk factors and outcome evaluated by the SOFA score". Intensive Care Med 26(7): 915-921.

5. Metnitz, P. G., et al. (2002). "Effect of acute renal failure requiring renal replacement therapy on outcome in critically ill patients". Crit Care Med 30(9): 2051-2058

6. Piccinni, P., et al. (2011). "Prospective multicenter study on epidemiology of acute kidney injury in the ICU: a critical care nephrology Italian collaborative effort (NEFROINT)". Minerva Anestesiol 77(11): 1072-1083.

7. Schrier R. W. and W. Wang (2004). "Acute renal failure and sepsis". N Engl J Med 351(2): 159-169.

8. Uchino, S., et al. (2005). "Acute renal failure in critically ill patients: a multinational, multicenter study". Jama 294(7): 813-818.

9. Singer M., et al. (2016). "The third international consensus definitions for sepsis and septic shock (sepsis-3)." JAMA 315(8): 801-810.

\section{KHẢO SÁT NGUYÊN NHÂN GÂY KHIẾM THỊ Ở NGƯờI VIỆT NAM}

\section{Nguyễn Thị Thu Hiền ${ }^{1}$, Trần Phương Anh ${ }^{1}$, Phạm Thị Minh Châu ${ }^{1}$}

\section{TÓM TẮT}

Mục tiêu: Khảo sát nquyên nhân gây khiếm thi ở người Việt Nam. Đối tướng: Nghiên cứu được thực hiện trên 886 người khiếm thị đến khám tại Phòng phuc hồi chức năng khiếm thi của Bênh viên Mắt Trung ươna trona 3 năm từ 2013 đến 2016. Phương pháp nghiên cứu: mô tả cắt ngang. Kết quả: trên 886 đối tượng gồm: 515 nam và 371 nữ, trong đó trẻ em là 478 (tuổi trung bình $9.23 \pm 3.2$ ) và người lớn là 408 (tuổi trung bình $29.71 \pm 14.1$ ). Các nhóm bệnh gây khiếm thị thường gặp gồm: bệnh lý võng mạc $27.2 \%$ (thoái hóa sắc tố võng mạc 46.4\%; bệnh võng mac trẻ đẻ non $15.8 \%$; thoái hóa hoàng điểm $14.5 \% \ldots$ ), bệnh lý thể thủy tinh $24.3 \%$ (đã lấy thể thủy tinh $4 \dot{4} .2 \%$, đã đăt thể thủy tinh nhân tao $40 \%$...), nhóm tật khúc xạ chiếm $16.7 \%$ (cận thị $63.5 \% \ldots)$. Tuy nhiên, giữa hai đối tương trẻ em và người lớn tỷ lệ phân bố các nguyên nhẩn không giống nhau: ở trẻ em nhóm bệnh lý võng mạc chiếm tỷ lế cao nhất (28.2\%); nhóm tât khúc xa đứng thứ hai (20.5\%); nhóm bệnh lý thể thủy tinh đứng thứ ba

${ }^{1}$ Bệnh viện Mắt Trung Ương

Chịu trách nhiệm chính: Nguyễn Thị Thu Hiền

Email: thuhienvnio@gmail.com

Ngày nhận bài: 16.12.2020

Ngày phản biên khoa hoc: 22.01.2021

Ngày duyệt bài: 8.2 .2021
(19.9\%); còn ở người lớn nhóm bệnh lý thể thủy tinh chiếm tỷ lệ cao nhất (29.4\%); nhóm bênh lý võng mac đứng thứ hai $(26.0 \%)$; nhóm tật khúc xa và nhóm bênh lý thi thần kinh đứng thứ ba $(12.3 \%)$. Kết luận: Nguyên nhân gây khiếm thị ở người Việt Nam đứng thứ nhất là do bênh lý võng mac, đứng thứ hai là bệnh lý thể thủy tinh và đứng thứ ba là tật khúc xạ.

Từ khóa: nguyên nhân, khiếm thị.

\section{SUMMARY SURVEYING THE CAUSES OF LOW VISION IN VIETNAM}

Obiective: To survey the causes of low vision in Vietnam. Research methods: cross-section study with 886 patients (515 males, 371 females) participated from 2013 to 2016 in low vision unit in Vietnam National Eye Hospital, there were 478 children (mean age $9.23 \pm 3.2$ years old) and 408 adults (mean age $29.71 \pm 14.1$ years old). Results: Causes of low vision included retinal diseases $27.2 \%$ (retinitis pigmentosa $46.4 \%$, retinopathy of prematurity $15.8 \%$, macular degeneration $14.5 \% \ldots$ ), lens-related disorders $24.3 \%$ (after cataract surgery: aphakia $44.2 \%$, intraocular lens implants $40 \% \ldots$, refractive errors $16.7 \%$ (by myopia $63.5 \% \ldots$...). However, there was a different contribution of low vision causes between children and adults. In children ( $\leq 15 y \mathrm{rs}$ ), the leading causes were retinal diseases $28.2 \%$, then refractive errors $20.5 \%$, lens-related 